\title{
FERRUGINOUS HAWK BANDING IN SASKATCHEWAN
}

\begin{abstract}
C. STUART HOUSTON, 863 University Drive, Saskatoon, SK S7N 0J8, WAYNE C. HARRIS, Saskatchewan Environment and Renewable Resources, 350 Cheadle St., West, Swift Current, SK S9H 4G3, and

ADAM SCHMIDT, Saskatchewan Environment and Renewable Resources, Box 2170, Melville, SK SOA 2P0
\end{abstract}

Ferruginous Hawks are of interest and concern, because they experienced a marked reduction in range in the first half of this century as grasslands were plowed, ${ }^{4}$ and showed a steady decline in productivity (measured as young per successful nest) between 1988 and 1996, and because many other grassland species, especially the Burrowing Owl and Sprague's Pipit, are showing population declines disproportionate to the more gradual loss of pasture area.

In the 1930s the late W. Ray Salt was the leading bander of Ferruginous Hawks in North America. Between 1930 and 1937 he banded 104 nestlings near Rosebud, Alberta ( $82 \%$ of those banded in all North America through 1938). From these hawks there were 22 recoveries, which mapped nicely their migration pathway. ${ }^{5}$ Sixty-eight percent were reported shot, reflecting the common sentiment of the time that "the only good hawk is a dead hawk," and helping to explain the remarkably high $(21 \%)$ recovery rate.

In contrast, nothing has been reported about the movements of this species from Saskatchewan. We herewith report on the results of banding 3601 nestling Ferruginous Hawks (of which 2651 have been banded by $\mathrm{CSH}$ with 50 recoveries, 488 by $\mathrm{WCH}$ with 27 recoveries, and 295 by AS with 10 recoveries). Another 109 were banded by members of the Saskatchewan
Falconry Association as subpermittees of Richard W. Fyfe of Edmonton (3 recoveries), and 22 by Douglas W.A. Whitfield (1 recovery). There were no recoveries from 21 banded by Glen $A$. Fox, 10 by Josef K. Schmutz, 3 by $M$. Ross Lein and 2 by Fred $G$. Bard. Years with greatest number of hawks banded were 1987 (409), 1990 (416), 1994 (201), and 1997 (232).

More than any other raptor, Ferruginous Hawks tend to return to the same nest site, year after year. This simplifies the task of finding nests in subsequent years, the extreme example being a solitary Manitoba maple on the Kindersley-Elna PFRA Pasture near Kindersley. In this tree, Ferruginous young were raised successfully for 28 consecutive years (possibly a world record for any raptor?) before the adult hawk was predated on the nest, perhaps by a Golden Eagle. ${ }^{3}$ The nest has been successful for four consecutive years since.

Now that this beneficial hawk is rarely shot, the recovery rate has dropped to $3 \%$ or slightly less, and below $2 \%$ since 1990. Of the 94 recoveries received through the end of 1994, 15 were killed on highways, 9 were shot, 7 electrocuted, 3 injured, and 1 each caught in a fence, trampled by a cow, and retrapped by the bander on its wintering grounds. Five were simplymarked 'band obtained,' two were on a skeleton, and 46 were found dead 
from no definite cause.

Although the longevity record for North America is of a 20-year-old Strongfield, Saskatchewan hawk with an inscribed leather neck collar and bell rather than a band, ${ }^{2}$ the 90 records suitable for assessment of longevity have shown disappointingly low longterm survival. In fact, $58(64 \%)$ of banded hawks died in their first 12 months, 9 between 13 and 23 months, then $8,5,4,1,2,1$, and 2 (the two oldest hawks living to 8 years).

The migratory path of Saskatchewan

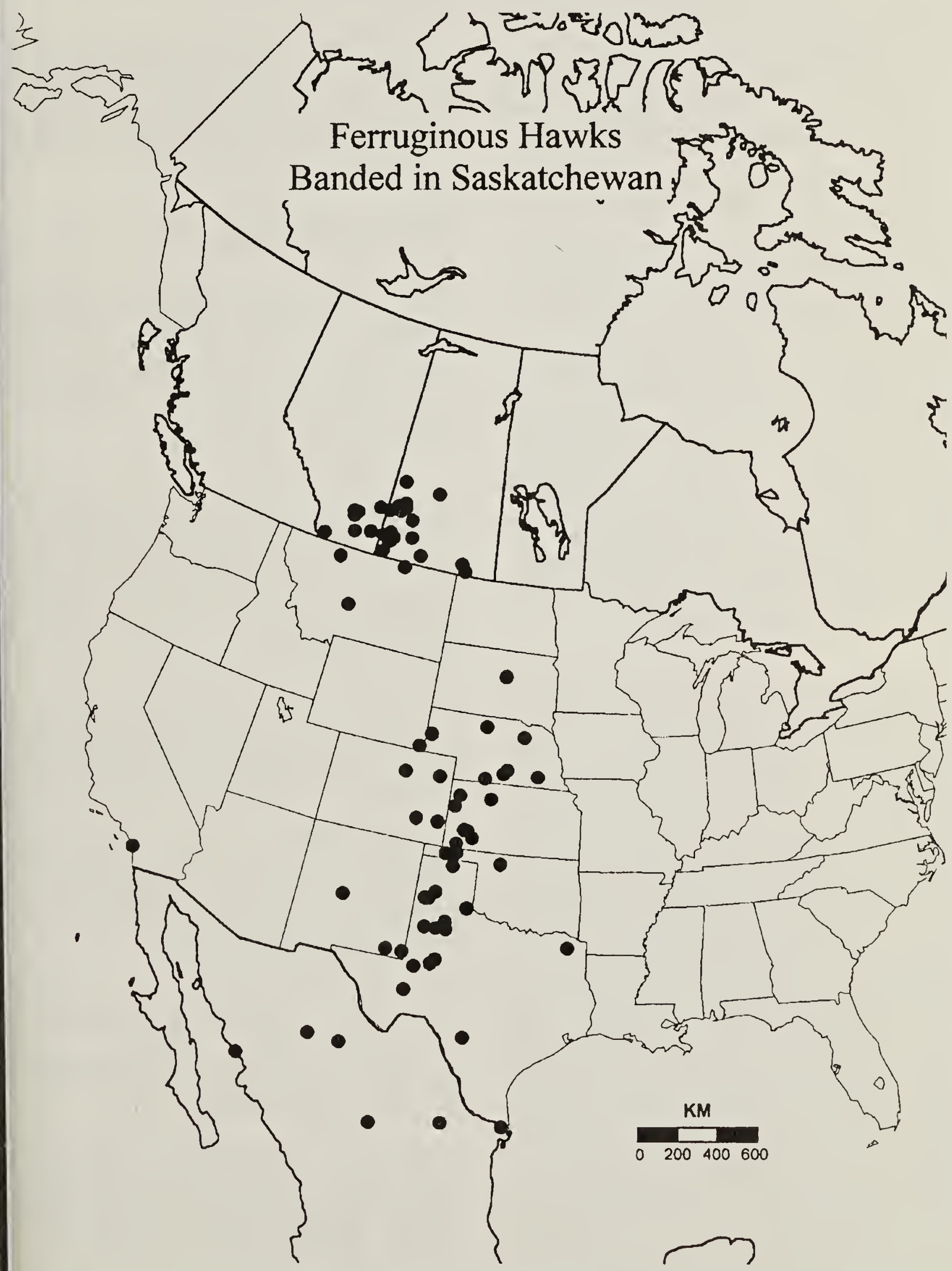

Figure 1. Ferruginous Hawks Banded in Saskatchewan 
Ferruginous Hawks is almost directly south, passing mainly through Nebraska, Kansas, southeast Colorado, the panhandle of Oklahoma and western Texas, keeping east of the Rocky Mountains (Fig. 1). Those travelling the greatest distance were the seven recovered in Mexico; only six of these could be mapped, since the seventh recovery location was simply "Mexico," with no locality specified. These six went $2300,2330,2690,2960,2970$, and 3030 $\mathrm{km}$ distant from hatching sites, the last being a hawk banded at Smiley, Saskatchewan and recovered the following May at Matamoros, Coahuila.

As with Salt's early Alberta recoveries, there was a single recovery in California, ours near San Clemente. Another, from the extreme western boundary of Saskatchewan south of Alsask, also crossed to Huatabampo, Sonora, on the Gulf of Mexico. Otherwise the Alberta and Saskatchewan hawks follow similar paths, with very little overlap with those breeding on the west side of the Rocky Mountains, which tend to keep farther west as they migrate south. ${ }^{1}$

Not shown on the map are fourteen recoveries in Saskatchewan that had been banded elsewhere. Seven, banded as nestlings in Alberta, were recovered in extreme western Saskatchewan, including one recovered in the nesting season when more than six years old. Five nestlings banded in North Dakota were found dead in Saskatchewan within $160 \mathrm{~km}$ of the 49th parallel; the two recovered in May and June were 260 and $580 \mathrm{~km}$ from their natal site, in their 5 th and 3 rd summers, respectively, respresenting unusually great dispersal for this species; those in late July, September and October were 320,485 and $425 \mathrm{~km}$, respectively. An unusual report is that of a nestling female banded near Salmon Falls Creek in extreme southern Idaho near the
Nevada boundary, which was found dead on 16 December east of Saskatoon Saskatchewan, when ten years old. An adult banded in January on its wintering grounds in Kansas by R.M. Imler, was no doubt back on its breeding territory when shot near Bengough, Saskatchewan, the next June.

As an added note, Ferruginous Hawk numbers now appear to be steady. Productivity rebounded to as-good-asever levels, perhaps fuelled by unusually high vole numbers, in 1997.

\section{Acknowledgements}

We thank Andy Didiuk and Kathy Meeres, Canadian Wildlife Service, Saskatoon, for help in preparing the map, using CSH's new Atlas GIS mapping program.

1. GOSSETT, D. 1993. Studies of Ferruginous Hawk biology: Recoveries of banded Ferruginous Hawks from presumed eastern and western subpopulations. M. Sc. thesis, Boise State University.

2. HOUSTON, C.S. 1984. Unusual story - record 20-year longevity of Ferruginous Hawk. Blue Jay 42:99-101.

3. HOUSTON, C.S. 1995. Thirty-two consecutive years of reproductive success at a Ferruginous Hawk nest. J. Raptor Res. 29:282-283.

4. HOUSTON, C.S., and M.J. BECHARD. 1984. Decline of the Ferruginous Hawk in Saskatchewan American Birds 38:166-170.

5. SALT, W.R. 1939. Notes on recoveries of banded Ferruginous Rough-legged Hawks. Bird-Banding 10:80- 85. 